\title{
EFFECTS OF THE ISOLATION CONDITIONS ON MORPHOLOGY AND PERFORMANCE OF HONEY BEES
}

\author{
İzolasyon Koşullarının Bal Arılarının Morfolojisi ve Performansına Etkileri
}

\author{
Mahmoud M.H. KELANY ${ }^{1}$, Hossam F. ABOU-SHAARA ${ }^{2}$ \\ 1Department of Plant Protection, Desert Research Center, Cairo, EGYPT, ORCID No: 0000-0003-3337-7552, Yazışma \\ Yazarı/Corresponding author E-mail: mahmoudelkelany@drc.gov.eg. \\ ${ }^{2}$ Department of Plant Protection, Faculty of Agriculture, Damanhour University, Damanhour, 22516, EGYPT, ORCID \\ No: 0000-0001-7208-6526, E-posta: hossam.farag@agr.dmu.edu.eg
}

Geliş Tarihi / Received: 11.09.2021

Kabul Tarihi / Accepted: 15.10.2021

DOI: 10.31467/uluaricilik.994233

\begin{abstract}
Keeping honey bee colonies in isolated areas can cause inbreeding. The inbreeding over a long period is good for the purity of bee subspecies but also has some negative effects including the low performance of colonies. This study was performed on hybrid honey bee colonies placed in an isolated location for about five years to check the effects of inbreeding on them. The bees were able to mate with each other during this period of time without introducing new bee queens or bee packages. Some morphological characteristics and parameters were studied to test the purity of the bees and the presence of any negative effects due to inbreeding. The results showed the presence of variations between studied colonies without any negative effects on bee morphology, hygienic behavior, bee larvae development, brood rearing activity, and food storing activity. The study highlighted the absence of deleterious effects on honey bees due to inbreeding under isolation conditions.
\end{abstract}

Key Words: Inbreeding, Apis mellifera, hygienic, endogamy, purity

Öz

Bal arısı kolonilerinin izole alanlarda tutulması akrabalı üremeye neden olabilir. Akrabalı yetiştirmenin uzun bir süre boyunca yapılması, arı alt türlerinin saflığı için iyidir ancak aynı zamanda kolonilerin düşük performansı da dahil olmak üzere bazı olumsuz etkileri de vardır. Bu çalışma, akrabalı yetiştirmenin etkilerini kontrol etmek için yaklaşık beş yıl boyunca izole bir yere yerleştirilen hibrit bal arısı kolonileri üzerinde yapıldı. Arılar, bu süre zarfında yeni ana arılar veya arı paketleri sunmadan birbirleriyle çiftleşebildiler. Arıların saflığını ve akrabalı yetiştirmeden kaynaklanan olumsuz etkilerin varlığını test etmek için bazı morfolojik özellikler ve parametreler incelenmiştir. Sonuçlar, arı morfolojisi, hijyenik davranış, arı larva gelişimi, yavru yetiştirme aktivitesi ve gıda depolama aktivitesi üzerinde herhangi bir olumsuz etki olmaksızın çalışılan koloniler arasında varyasyonların varı̆̆ını göstermiştir. Çalışma, izolasyon koşulları altında akrabalı yetiştirme nedeniyle bal arıları üzerinde zararlı etkilerin olmadığını vurguladı.

Anahtar Kelimeler: Akrabalı yetiştirme, Apis mellifera, hijyenik, endogami, saflık 


\section{ARAŞTIRMA MAKALESI / RESEARCH ARTICLE}

\section{GENIŞLETILMIŞ ÖZET}

Amaç: İzole bir çöl bölgesinde akrabalı yetiştirmenin arı kolonileri üzerindeki etkisini bilmek.

Gereç ve Yöntem: Çalışma güneyde (Abu Simbel bölgesi) izole bir alanda bulunan bir arı kovanı üzerinde gerçekleştirilmiştir. Konum ( $22^{\circ} 24^{\prime} 21.6^{\prime \prime} \mathrm{K}$, $31^{\circ} 32^{\prime}$ 41.64" E), arıların akrabalı yetiştirmeye maruz kalmasını sağlamak için bu arılığa yeni kraliçeler veya arı paketleri eklenmedi.

Bu çalışmayı yapmak için 2019 yazında arılıktan rastgele seçilen aynı güçte altı kovandan bal arısı örnekleri toplandı. Elli işçi arı alkollü kavanozlara alınarak morfometrik analize hazırlandı. Kanatlar ve bacaklar arılardan ayrıldı, cam slaytlara monte edildi ve net görüntüler için 1200 dpi'de bir Hp Deskjet 2050A ile tarandı. Görüntüler daha sonra El-Aw ve arkadaşlarına göre tarama teknolojisi (SPT) kullanılarak ön uzunluk ve genişlik ile arka bacakların tibial ve baziler uzunluklarını ölçmek için kullanıldı (2012). Ölçülen özellikler daha sonra kovanlar arasındaki farkları ortaya çıkarmak için istatistiksel analize tabi tutuldu.

Abu Shaara ve Ahmed (2015) tarafından yürütülen bir çalışmada, Carniolan melezlerinden alınan işçi arı örneklerinin morfolojik özellikleri ölçülmüş ve yayınlanmıştır. Yayınlanan karakteristik aralıklar, melez arılar için normatif değerler olarak alınmıştır. İzole edilmiş arılıktaki arıların ölçülen özellikleri daha sonra, izole edilmiş arılarda akrabalı yetiştirme nedeniyle meydana gelen değişiklikleri belirlemek için standart değerlerle karşılaştırılmıştır.

-Hijyenik davranış: Pupaları öldürmek için kuluçka tarağının ortasındaki 50 kapalı hücre küçük bir iğne ile delindi. Kolonilerin hijyenik davranışını değerlendirmek için 24 saat sonra temizlenen hücreler sayıldı. Bu test bir ay arayla üç kez tekrarlandı ve ardından her kovan için üç testin ortalaması hesaplandı. Ortalamalar, kolonilerdeki hijyenik davranışın tutarııı̆ını kontrol etmek için istatistiksel olarak karşılaştırıldı.

-Yumurtadan ergine gelişim:

Yumurtaların normal olarak larvalara, larvalardan pupalara ve pupalardan yetişkinlere yumurtadan çıkma yeteneği değerlendirildi. Her kovanda yaklaşık 100 yumurta içeren bir alan işaretlendi ve ardından yumurtadan çıkana kadar olan gelişim kaydedildi. Bu deney: Eylül ve Kasım aylarında iki kez tekrarlandı.
-Damızlık yetiştirme ve yiyecek depolama faaliyetleri.

Eylül, Ekim ve Kasım aylarında kuluçka ve yiyecek depolama faaliyetleri kaydedildi. Bu aktiviteleri ölçmek için inç2'ye bölünmüş bir çerçeve (Jeffree 1958) kullanıldı. Kaydedilen araçlar daha sonra kovanlar arasındaki tutarlılığı bulmak için karşılaştırıldı.

\section{Sonuç:}

\section{Arı morfolojisi:}

Ölçülen morfolojik özellikler, işçi arılar için kaval kemiği uzunluğu ve arı erkek arılar için ön kanat uzunluğu dışında, ölçülen özelliklerin çoğunda önemli farklılıklar kaydedildiğinden çok yüksek özdeş değerlerin olmadığını göstermiştir. Bu, beş yıllık izolasyondan sonra arıların hala melez bir yapıya sahip olduklarını yansıtmaktadır. Bununla birlikte, minimum, medyan ve maksimum değerler açısından tanımlayıcı veriler, kolonilerin saflık ve özelliklerin tutarlılığına yöneldiğini desteklemektedir. $\mathrm{Bu}$ nedenle, işçi arılar tarafından paylaşılan özdeş değerler \%28 ile \%96 arasında değişmektedir ve bu benzerlikler izolasyon koşullarında yaklaşık beş yıllık akrabalı yetiştirmenin etkisiyle açıklanabilir.

\section{Hijyenik davranış:}

Toplam ortalamalara göre $\% 80$ 'den fazla uzaklaştırma yüzdesi ile sadece beş kovanın hijyenik trendle kabul edilebileceği açıktır. Elde edilen sonuçlar ışığında, incelenen kolonilerde 5 yılı aşkın akrabalı yetiştirmenin hijyen eğilimini olumsuz etkilemediği görülmüştür.

\section{Yumurtadan ergine gelişim:}

İzole lokasyonda bulunan kovanlarda arıların gelişimi normaldi ve zamanla akrabalı yetiştirmeden olumsuz etkilenmedi. Çalışma yerinin çöl doğasına rağmen arıların gelişimi üzerinde herhangi bir zararlı etkisinin olmadığı açıktır. Ayrıca, izolasyon koşullarında akrabalı yetiştirme nedeniyle arıların gelişimi herhangi bir genetik sürüklenmeden etkilenmemiştir.

4. Kuluçka yetiştirme ve yiyecek depolama faaliyetleri:

Mısır'ın melez arılarının zorlu çevre koşulları altında normal olarak kuluçkaya yatma yeteneği, AbouShaara ve arkadaşları (2013b) tarafından önceki çalışmalarda, bir çöl bölgesinde gerçekleştirilen mevcut çalışma ile uyumludur. Tüm koloniler aynı güce sahipti, ancak kuluçka yetiştirme ve yiyecek 


\section{ARAŞTIRMA MAKALESI / RESEARCH ARTICLE}

depolama faaliyetleri, araçlara bağlı olarak kovandan kovana değişiyordu. Ancak, kovanlar arasında önemli farklılıklar sadece kuluçka faaliyetinde tespit edilmiştir. Genel olarak, bu çalışma, hibrit arılardan thelytokous olmadan saf arı elde etmek için yaklaşık beş yıllık bir sürenin yeterli olmadığını vurgulamaktadır.

\section{INTRODUCTION}

Honey bees, Apis mellifera L., are considered as typical social insects. They live in colonies consist of one reproductive female (queen), thousands of infertile females (workers), and hundreds of males (drones). The presence of one reproductive female increases the possibility of inbreeding in bee colonies through endogamy. However, honey bees naturally avoid inbreeding as queen mates in the air with a lot of bee drones (Taber and Wendel 1985, Moritz et al. 1996, Cobey 2007) at specific sites called drone congregation areas (Zmarlicki and Morse 1963). Such high number of drones ensures the genetic variations inside the colonies. The number of sperm inside the spermatheca of a mated queen can reach to 4.54 million (Kaftanoglu and Peng 1982). Sperm can stay alive for a long period inside the spermatheca, and secretions from spermathecal glands have a key role in this (den Boer et al. 2009). Studies have shown that mating with high number of drones is better than mating with a single drone, and sufficiently with seven mates as the minimum (Tarpy et al. 2012, Delaplane et al. 2015).

The queens under normal conditions can lay high number of eggs per day (Moore et al. 2015). Two types of eggs are laid by the queens: fertilized eggs and unfertilized ones (Ratnieks and Keller 1998). The fertilized eggs hatch to new workers or queens. The fertilization of eggs ensures the genetic variations as a result of the combination of genetic materials from the egg cells and sperm cells, especially the complementary sex determiner gene should be heterozygous in females (Beye et al. 2003). Drones are mainly result from the unfertilized eggs. The characteristics of bee drone are typical to its mother without huge variations between them. The inbred queens can lay fertilized eggs in worker cells which develop into weak drone larvae, but such larvae are rapidly eaten by workers (Woyke 1963, Woyke 1964). Basically, many apiaries are placed close to each other, and this ensures the presence of high number of drones at the drone congregation areas and from various genetic sources. Under certain circumstances, apiaries can be established in isolated areas including islands, newly reclaimed desert areas or mountainous areas.

The main problem of the isolated areas is the possibility of exposing bees to inbreeding and the low performance of the colonies due to endogamy. The main benefit of inbreeding is increasing the purity of bee stocks and can enhance some traits of bee colonies including calmness (Bienefeld et al. 1989). Most of honey bee populations are characterized by the average level of inbreeding due to the features of their life and biology. Only hybrid populations of honey bees can be characterized with outbreeding (llyasov et al., 2015; 2016). The purity of honey bees as well as the negative effects of inbreeding can be screened by studying bee morphology and colony performance parameters. Morphological characteristics can be utilized to examine the purity of bee subspecies (Bienefeld et al. 1996, Radloff et al. 2003, Abou-Shaara et al. 2013a), and are impacted by inbreeding (Roberts 1961, Brückner 1979). Hygienic behavior depends on genetic characteristics of bees without great influence of environmental conditions or colonies status on it (Bigio et al. 2013, Xonis et al. 2015), and can be improved through selection and breeding (Palacio et al. 2000, Pernal et al. 2012, Gerula et al. 2015). Behaviors and performance of bees can be impacted by inbreeding (Brückner 1980; Oldroyd and Goodman 1988, Bienefeld et al.1989, Cermak 1996). The small morphological characteristics, low hygienic ability, abnormal development of bees, and low bee activities are expected to bee colonies under isolation conditions because of inbreeding.

Therefore, this study was performed on honey bee colonies placed at an isolated location for a period of about five years. These colonies were able to mate with each other only and no new queens or bee packages were introduced to this location. Some morphological characteristics of worker and drone bee samples were measured. Also, hygienic behavior, development of bee larvae, and activities of the colonies were studied. These parameters were employed to check the purity of the studied colonies as well as the negative effects of inbreeding on them. 


\section{ARAŞTIRMA MAKALESI / RESEARCH ARTICLE}

\section{MATERIALS AND METHODS}

\section{Study location and honey bee colonies}

An apiary was established in February 2015 in an isolated location in the south of Egypt (Abu Simbel region) (Abou-Shaara and Kelany, 2021). The location (22 $\left.24^{\prime} 21.6^{\prime \prime} \mathrm{N}, 31^{\circ} 32^{\prime} 41.64 " \mathrm{E}\right)$ of this apiary is shown in Fig. 1. Twenty hives with hybrids of Carniolan honey bees were placed in this apiary. The queens were replaced frequently from the same colonies and mated with drones from the same colonies over a period of about five years. Some bee colonies were lost during this period. However, no new queens or bee packages were introduced to this apiary to ensure the exposure of bees to inbreeding.

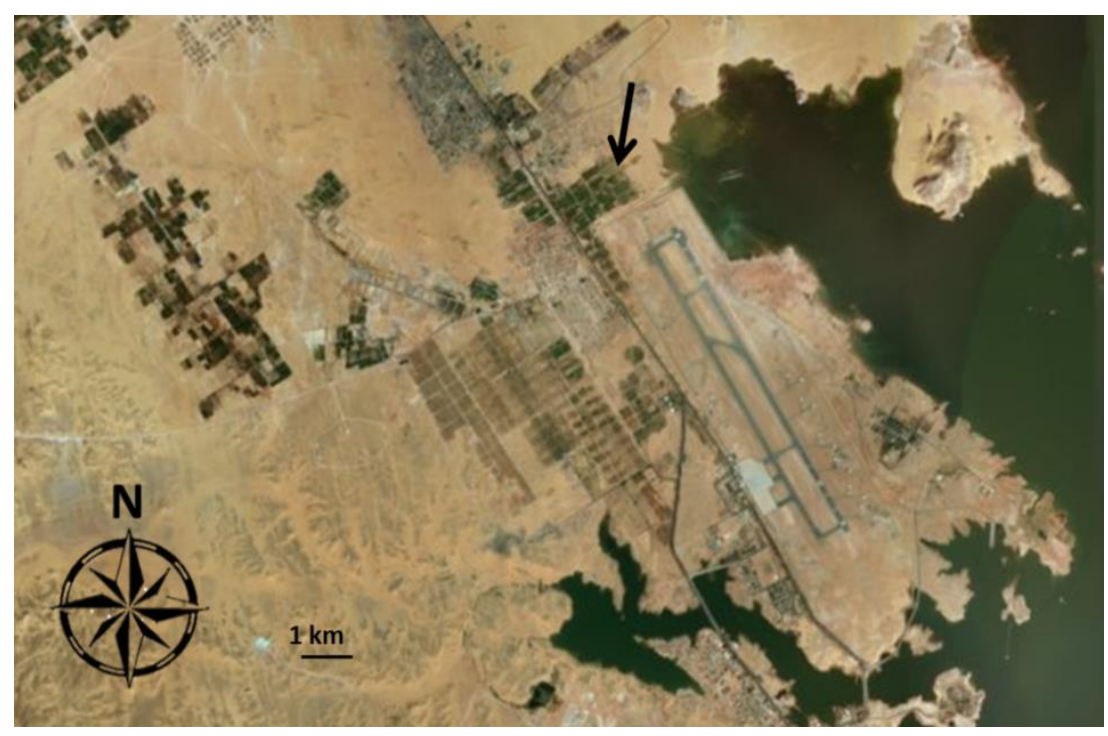

Fig.1: The location of the apiary (black arrow).

\section{Morphology of worker bees}

Six hives with similar strength of seven frames covered with bees were randomly selected from the apiary to perform this study during summer 2019 . From each hive 50 worker bees were collected from brood combs in jars contain alcohol and were then prepared for the morphometric analysis. The wings and legs were separated from the bees and were mounted on glass slides and scanned using $\mathrm{Hp}$ Deskjet 2050A at 1200 dpi to obtain clear images. The images were then used to measure forewing length and width, and lengths of tibia and basitarsus of the hind legs using the Scan Photo Technique (SPT) according to El-Aw et al. (2012). The measured characteristics were then subjected to the statistical analysis to detect the variations between the hives.

The morphological characteristics of bee worker samples from hybrids of Carniolan bees were measured and published in a study by Abou-Shaara and Ahmed (2015). The ranges of the published characteristics were considered as the standard values for the hybrid bees. Then, the measured characteristics of the bees from the isolated apiary were compared with the standard values to identify the changes in the isolated bees due to inbreeding.

\section{Morphology of honey bee drones}

From each hive ten drones were collected during late summer, and then were dissected and some morphological characteristics were measured as mentioned with worker bees. The measured characteristics were compared to check the consistency between hives. Low numbers of drones were collected from each hive because there were few drones in them.

\section{Hygienic behavior}

In each hive, 50 sealed cells at the middle of the brood comb were pierced with a tiny needle to kill the pupae. The number of cleaned cells was then 


\section{ARAŞTIRMA MAKALESI / RESEARCH ARTICLE}

counted after $24 \mathrm{~h}$ to assess the hygienic behavior of the colonies. This test was repeated three times with one month interval and then the mean of the three tests was calculated for each hive. The means were statistically compared to check the consistency of the hygienic behavior in the colonies.

\section{The development from eggs to adults}

The ability of eggs to hatch normally into larvae and from larvae to pupae and from pupae to adults was assessed. In each hive, an area containing about 100 eggs was marked and then the development until hatching was recorded. This experiment was repeated twice during September and November.

\section{Brood rearing and food storing activities}

The activities of brood rearing and food storing were recorded during September, October, and November. To measure these activities, a frame divided into inch ${ }^{2}$ (Jeffree 1958) was used. The recorded means were then compared to find out the consistency between the hives.

\section{Statistical analysis}

Normality of the data was checked using Kolmogorov-Smirnov and Shapiro-Wilk tests. For morphological characteristics, descriptive statistics were firstly calculated while means were compared using the non-parametric test (Kruskal-Wallis test). For the hygienic behavior data, Kruskal-Wallis test was used to compare means. The analysis of variance (ANOA) was utilized to identify the significant differences between means of brood rearing and food storing activities. The analysis at a significance level of 0.05 was conducted using the SPSS v. 16.

\section{RESULTS}

\section{Worker Morphology}

The descriptive statistics showed the presence of variations between hives based on mean and median values but with somewhat similar minimum and maximum values for the measured characteristics (Table 1). These variations were confirmed by the Kruskal-Wallis test as significant differences were found in forewing length (ChiSquare $=24.312, \quad d f=5, p=0.000<0.05)$, forewing width (Chi-Square $=45.819, \mathrm{df}=5, \mathrm{p}=0.000<0.05$ ), and basitarsus length (Chi-Square $=33.289, \mathrm{df}=5, \mathrm{p}=$ $0.000<0.05)$ while no significant differences were found in tibia length (Chi-Square $=6.748, d f=5, p=$ $0.240>0.05$ ). The percentages of worker bees with the identical minimum, median and maximum values from the six hives were 44 to $62 \%$ to forewing length, 28 to $72 \%$ to forewing width, 48 to $72 \%$ to the tibia length, and 54 to $96 \%$ to the basitarsus length.

The comparison between the measured characteristics and the standard values measured by Abou-Shaara and Ahmed (2015) are presented in Table 2. It is evident that the hives shared from 48 to $68 \%$, from 26 to $54 \%$, from 10 to $60 \%$, from 6 to $44 \%$, from 26 to $56 \%$, and from 22 to $54 \%$ with the standard values for hive 1 to 6 , respectively.

Table 1: Means $(\mathrm{mm}) \pm$ S.E. of measured body characteristics of worker bees from the six hives. Also, descriptive statistics of measured characteristics for the six hives are presented.

\begin{tabular}{ccccc}
\hline Hive & Forewing length & Forewing width & Tibia length & Basitarsus length \\
\hline $\mathbf{1}$ & $8.57 \pm 0.01$ & $2.97 \pm 0.01$ & $2.86 \pm 0.01$ & $2.02 \pm 0.01$ \\
$\mathbf{2}$ & $8.54 \pm 0.01$ & $2.95 \pm 0.01$ & $2.86 \pm 0.01$ & $2.04 \pm 0.01$ \\
$\mathbf{3}$ & $8.49 \pm 0.01$ & $2.85 \pm 0.01$ & $2.84 \pm 0.01$ & $2.06 \pm 0.01$ \\
$\mathbf{4}$ & $8.46 \pm 0.01$ & $2.90 \pm 0.01$ & $2.87 \pm 0.02$ & $2.01 \pm 0.01$ \\
$\mathbf{5}$ & $8.48 \pm 0.01$ & $2.88 \pm 0.01$ & $2.86 \pm 0.01$ & $1.95 \pm 0.01$ \\
$\mathbf{6}$ & $8.51 \pm 0.02$ & $2.91 \pm 0.01$ & $2.81 \pm 0.01$ & $2.05 \pm 0.01$ \\
Minimum & $8.2-8.3$ & $2.6-2.8$ & $2.6-2.7$ & $1.7-1.9$ \\
Maximum & 8.7 & $3-3.2$ & $3-3.1$ & $2.1-2.3$ \\
Median & $8.4-8.6$ & $2.9-3$ & $2.8-2.9$ & $2-2.1$ \\
\hline
\end{tabular}




\section{ARAŞTIRMA MAKALESİ / RESEARCH ARTICLE}

Table 2: Number of bees with identical values with the standard values measured by Abou-Shaara and Ahmed (2015) from the six hives.

\begin{tabular}{llllllll}
\hline $\begin{array}{l}\text { Characteristics } \\
\text { Standard value range }(\mathrm{mm})\end{array}$ & Hive number & 1 & 2 & 3 & 4 & 5 & 6 \\
& & & & & & & \\
\hline $\begin{array}{l}\text { Forewing length } \\
\text { Range (8.64-8.74) }\end{array}$ & Number of bees & 34 & 25 & 18 & 12 & 16 & 21 \\
& Total (\%) & $\mathbf{6 8}$ & $\mathbf{5 0}$ & $\mathbf{3 6}$ & $\mathbf{2 4}$ & $\mathbf{3 2}$ & $\mathbf{4 2}$ \\
& & & & & & \\
\hline Forewing width & Number of bees & 24 & 16 & 5 & 3 & 13 & 11 \\
Range (3.02-3.06) & Total (\%) & $\mathbf{4 8}$ & $\mathbf{3 2}$ & $\mathbf{1 0}$ & $\mathbf{6}$ & $\mathbf{2 6}$ & $\mathbf{2 2}$ \\
& & & & & & & \\
\hline Tibia length & Number of bees & 34 & 27 & 30 & 18 & 27 & 27 \\
Range (2.88-2.96) & Total (\%) & $\mathbf{6 8}$ & $\mathbf{5 4}$ & $\mathbf{6 0}$ & $\mathbf{3 6}$ & $\mathbf{5 4}$ & $\mathbf{5 4}$ \\
& & & & & & & \\
\hline Basitarsus length & Number of bees & 25 & 13 & 13 & 22 & 28 & 23 \\
Range (1.98-2.04) & Total (\%) & $\mathbf{5 0}$ & $\mathbf{2 6}$ & $\mathbf{2 6}$ & $\mathbf{4 4}$ & $\mathbf{5 6}$ & $\mathbf{4 6}$ \\
& & & & & & \\
\hline
\end{tabular}

\section{Drone morphology}

The descriptive statistics showed the presence of variations between hives (Table 3). These variations were confirmed by the Kruskal-Wallis test as significant differences were found in forewing width
(Chi-Square $=14.97, d f=5, p=0.01<0.05$ ), tibia length (Chi-Square $=14.87, \quad d f=5, \quad p=0.01<0.05$ ), and basitarsus length (Chi-Square $=22.10, d f=5, \quad p=$ $0.00<0.05$ ) while no significant differences were found in forewing length (Chi-Square $=8.59, \mathrm{df}=5, \mathrm{p}=$ $0.12>0.05)$.

Table 3: Means $(\mathrm{mm}) \pm$ S.E. of measured body characteristics of bee drones from the six hives. Also, descriptive statistics of measured characteristics for the six hives are presented.

\begin{tabular}{c|cccc} 
Hive & Forewing length & Forewing width & Tibia length & Basitarsus length \\
\hline $\mathbf{1}$ & $11.21 \pm 0.04$ & $3.95 \pm 0.07$ & $3.58 \pm 0.03$ & $2.49 \pm 0.03$ \\
$\mathbf{2}$ & $11.31 \pm 0.05$ & $4.12 \pm 0.03$ & $3.62 \pm 0.04$ & $2.69 \pm 0.03$ \\
$\mathbf{3}$ & $11.19 \pm 0.04$ & $4.02 \pm 0.05$ & $3.62 \pm 0.01$ & $2.61 \pm 0.03$ \\
$\mathbf{4}$ & $11.22 \pm 0.04$ & $3.88 \pm 0.05$ & $3.49 \pm 0.03$ & $2.50 \pm 0.03$ \\
$\mathbf{5}$ & $11.18 \pm 0.05$ & $4.01 \pm 0.04$ & $3.71 \pm 0.04$ & $2.65 \pm 0.03$ \\
\hline Minimum & $11.13 \pm 0.05$ & $3.86 \pm 0.05$ & $3.61 \pm 0.04$ & $2.62 \pm 0.02$ \\
Maximum & $11-11.1$ & $3.7-4$ & $3.4-3.6$ & $2.4-2.5$ \\
Median & 11.4 & $4.1-4.3$ & $3.7-3.9$ & $2.8-2.9$ \\
& $11.05-11.4$ & $3.85-4.15$ & $3.45-3.7$ & $2.5-2.7$ \\
\end{tabular}




\section{ARAŞTIRMA MAKALESI / RESEARCH ARTICLE}

\section{Hygienic behavior}

The three tests showed consistency in the results except hive 2 and 6 (Table 4). The percentages of the cleaned cells in the first test ranged from 44 to $100 \%$ and from 74 to $100 \%$ in the second test, and
$100 \%$ to all hives in the third test. The lowest value was recorded only to hive 6 during the first test. The overall means ranged from 79.33 to $100 \%$ without statistical variations between the six hives according to the Kruskal-Wallis test (Chi-Square $=5.168, \mathrm{df}=5$, $\mathrm{p}=0.39>0.05$ ).

Table 4: Hygienic behavior tests for the six hives. Percentages of cleaned cells after $24 \mathrm{~h}$ are presented.

\begin{tabular}{ccccccc}
\hline Test number & \multicolumn{7}{c}{ Hive number } \\
\cline { 2 - 7 } & $\mathbf{1}$ & $\mathbf{2}$ & $\mathbf{3}$ & $\mathbf{4}$ & $\mathbf{5}$ & $\mathbf{6}$ \\
\hline $\mathbf{1}$ & 100 & 94 & 100 & 100 & 100 & 44 \\
\hline $\mathbf{2}$ & 100 & 74 & 80 & 70 & 100 & 94 \\
\hline $\mathbf{3}$ & 100 & 100 & 100 & 100 & 100 & 100 \\
\hline Mean $\mathbf{E}$ S.E. & $\mathbf{1 0 0 \pm 0 . 0 0}$ & $\mathbf{8 9 . 3 3 \pm 7 . 8 6}$ & $\mathbf{9 3 . 3 3 \pm 6 . 6 7}$ & $\mathbf{9 0 \pm 1 0}$ & $\mathbf{1 0 0 \pm 0 . 0 0}$ & $\mathbf{7 9 . 3 3 \pm 1 7 . 7 5}$ \\
\hline
\end{tabular}

\section{The development from eggs to adults}

In all the studied hives, eggs were able to hatch normally into larvae and from larvae to pupae, and from pupae to adults with percentages of $100 \%$.

\section{Brood rearing and food storing activities.}

Only sealed brood area differed significantly (ANOVA, $\mathrm{df}=5, \mathrm{~F}=7.627, \mathrm{p}=0.02<0.05$ ) between the hives. Hive 4 and 5 had the lowest brood rearing area. Stored pollen area (ANOVA, $\mathrm{df}=5, \mathrm{~F}=0.84$, $\mathrm{p}=0.54>0.05$ ) and stored honey area (ANOVA, $\mathrm{df}=$ $5, \mathrm{~F}=2.375, \mathrm{p}=0.10>0.05)$ exhibited insignificant variations (Table 5).

Table 5: Brood rearing and food storing activities (Means \pm S.E. in inch ${ }^{2}$ ) for the six hives. Means marked with different letters denote to the presence of significant differences according to Tukey HSD test.

\begin{tabular}{llll}
\hline Hive & \multicolumn{1}{c}{$\begin{array}{c}\text { Sealed brood } \\
\text { area }\end{array}$} & $\begin{array}{c}\text { Stored pollen } \\
\text { area }\end{array}$ & $\begin{array}{c}\text { Stored honey } \\
\text { area }\end{array}$ \\
\hline 1 & $349.67 \pm 64.23 \mathrm{ab}$ & $31.33 \pm 10.26$ & $227.33 \pm 21.94$ \\
2 & $397.67 \pm 42.88 \mathrm{a}$ & $54.00 \pm 35.67$ & $557.00 \pm 59.28$ \\
3 & $460.67 \pm 57.77 \mathrm{a}$ & $73.33 \pm 33.54$ & $427.33 \pm 162.74$ \\
4 & $117.67 \pm 15.34 \mathrm{~b}$ & $27.33 \pm 13.22$ & $136.67 \pm 10.36$ \\
5 & $142.67 \pm 76.52 \mathrm{~b}$ & $33.00 \pm 9.00$ & $387.67 \pm 157.98$ \\
6 & $352.00 \pm 9.86 \mathrm{ab}$ & $20.67 \pm 6.96$ & $271.67 \pm 53.16$ \\
\hline
\end{tabular}

\section{DISCUSSION}

\section{Bee morphology}

The measured morphological characteristics showed the absence of very high identical values as significant differences were recorded in most measured characteristics except tibia length for worker bees and forewing length for bee drones. This reflects that the bees after five years of isolation still had hybrid nature. However, the descriptive data in terms of minimum, median, and maximum values support that the colonies tend towards purity and consistency of characteristics. Therefore, the identical values shared by worker bees ranged from 


\section{ARAŞTIRMA MAKALESI / RESEARCH ARTICLE}

28 to $96 \%$, and these similarities can be explained by the impact of inbreeding over about five years under the isolation conditions. The similarities are not very high likely because the period of five years is not sufficient to turn bee colonies into pure bees instead of their hybrid status.

Hybrid bees are mostly larger than inbred bees (Roberts 1961). In the present study, the morphological characteristics of worker bees under isolation conditions (i.e. inbred bees) showed similarities (from 6 to $68 \%$ ) with the standard values of hybrid bees measured by Abou-Shaara and Ahmed (2015). Therefore, the bees were impacted slightly by the inbreeding especially hive 4 because some of the measured characteristics were less than the standard ranges of the hybrid bees.

The means of forewing length, forewing width, and basitarsus length for the six hives ranged from 8.46 to $8.57 \mathrm{~mm}, 2.88$ to $2.97 \mathrm{~mm}$, and 1.95 to $2.06 \mathrm{~mm}$, respectively. The values of these characteristics in respect are 8.23, 2.78, and $1.96 \mathrm{~mm}$ for the Egyptian bees, Apis mellifera lamarckii, (Data Bank, Oberursel Frankfurt, Germany), and 9.17, 3.19, 2.42 $\mathrm{mm}$ for the Carniolan bees, Apis mellifera carnica (Yakoub 2002). Therefore, the obtained values for the studied hives were moderate between the values of the two subspecies. This confirms the hybrid status of these bees between the Egyptian and Carniolan bees.

\section{Hygienic behavior}

$t$ is clear that only five hives can be considered with a hygienic trend with a removal percentage of more than $80 \%$ based on the overall means. Hive 6 was different than the other hives due to the low hygienic ability during the first test. In light of the obtained results, the inbreeding over 5 years did not impact the hygienic trend negatively in the examined colonies. The obtained results are in line with those found by Abou-Shaara et al. (2018) for hybrid bees of Egypt, as the percentages of the cleaned cells ranged from 82 to $89 \%$. However, the present study is on the contrary with the study by Balhareth et al. (2012) on hybrid bees of Egypt under Saudi Arabia conditions, as the mean of the cleaned cells was $79.32 \%$ to the studied colonies. This can be attributed mainly to the arid conditions of Saudi Arabia, which negatively impacted bee populations and subsequently their hygienic trend.

\section{The development from eggs to adults}

The development of bees in the hives located at the isolated location was normal and has not been impacted negatively by inbreeding over time. It is known that egg hatching is negatively impacted by unsuitable levels of temperature and relative humidity (Al-Ghamdi et al. 2014), and harsh conditions can passively affect egg hatching and development of bees (Abou-Shaara et al., 2017). So, it is evident that the study location has no deleterious effects on the development of bees although it is a desert nature. Also, the development of bees was not impacted by any genetic drift due to inbreeding under isolation conditions.

\section{Brood rearing and food storing activities}

The ability of the hybrid bees of Egypt to rear brood normally under harsh environmental conditions was confirmed in previous studies by Abou-Shaara et al. (2013b) and Kelany (2018), and this is in line with the present study which was performed at a desert region. All colonies had the same strength but brood rearing and food storing activities varied from hive to another based on means. However, significant differences between hives were detected only in brood rearing activity. The low brood rearing activity in hive 4 and 5 than the other hives can be partially explained by inbreeding. The absence of significant variations between hives in the stored pollen and honey areas suggested the same ability of hives to store food. In fact, effects of inbreeding on honey production can be negative (Bienefeld et al. 1989) or positive (Cermak 1996). These indicate that effects of inbreeding on food storing activity are not constant and can be affected by other factors than inbreeding. In a similar way, Oldroyd and Goodman (1988) found that colonies with hybrid queens did not have higher honey production than colonies with inbred queens. Overall, the present study highlights that the period of about five years is not sufficient to obtain pure bees from the hybrid bees without thelytoky. For comparison, the thelytokous Cape honey bees, Apis mellifera capensis, showed high levels of heterozygosity after inbreeding for 10 years (Oldroyd et al. 2011) and 20 years (Smith et al. 2019).

\section{Conclusion}

The small morphological characteristics, low hygienic ability, abnormal development of bees, and low bee activities are expected to bee colonies after five years from isolation as a result of inbreeding. On the contrary, the study showed no deleterious effects 


\section{ARAŞTIRMA MAKALESI / RESEARCH ARTICLE}

on the morphology or performance of honey bees after isolation for about five years. The bees had noticeable and significant variations in the measured parameters without low levels of hygienic behavior or abnormal development of bees, suggesting that the negative effects of inbreeding were not high.

Source of Finance: Not applicable because there is no funding source for this study

Conflict of Interest: Authors declare that they have no any conflict of interests to be reported.

Author contribution: The authors contributed equally in the study. They designed, performed, analyzed the data, wrote and revised the manuscript.

Ethical issue: Not applicable because this study on honey bees and not animals or humans.

\section{REFERENCES}

Abou-Shaara, HF., Ahmed, ME. 2015. Characterisation and tracking changes of morphological characteristics in honey bee, Apis mellifera, colonies, Journal of Entomological and Acarological Research, 47(3), 103-108.

Abou-Shaara, H.F., Kelany, M.M. 2021. A methodology to assist in locating drone congregation area using remote sensing technique. J. Apic. Res. 1-3. https://doi.org/10.1080/00218839.2021.1898 786

Abou-Shaara, HF., Al-Ghamdi, AA., Mohamed, AA. 2013a. Body morphological characteristics of honey bees, Agricultura, 10, 45-49.

Abou-Shaara, HF., Al-Ghamdi, AA., Mohamed, AA. 2013b. Honey bee colonies performance enhance by newly modified beehives, Journal of Apicultural Science, 57(2), 45-57.

Abou-Shaara, HF., Owayss, AA., Ibrahim, YY., Basuny, NK. 2017. A review of impacts of temperature and relative humidity on various activities of honey bees, Insectes sociaux, 64(4), 455-463.

Abou-Shaara, HF., M. Poliak, M., Čermáková, T. 2018. Field and laboratory assessment to hygienic behavior of Carniolan honey bees with studying impacts of oxalic acid on grooming behavior, Munis Entomology and Zoology, 13 (1): 256-265.

Al-Ghamdi, AA., Abou-Shaara, HF., Mohamed, AA. 2014. Hatching rates and some characteristics of Yemeni and Carniolan honey bee eggs, Journal of Entomology and Zoology Studies, , 2(1), 6-10.

Balhareth, HM., Alqarni, AS., Owayss, AA. 2012. Comparison of hygienic and grooming behaviors of indigenous and exotic honeybee, Apis mellifera races in central Saudi Arabia, Int. J. Agric. Biol., 14: 1005-1008.

Beye, M., Hasselmann, M., Fondrk, MK., Page, RE., Omholt, SW. 2003. The gene csd is the primary signal for sexual development in the honeybee and encodes an SR-type protein, Cell, , 114, 419-429.

Bienefeld, K., Reinhardt, F., Pirchner, F. 1989. Inbreeding effects of queen and workers on colony traits in the honey bee, Apidologie, 20(5), 439-450.

Bienefeld, K., Tahmasebi, GH., Keller, R., Kauhausen-Keller, D., Ruttner, F. 1996. Report on the Present Situation of Apis mellifera meda in Iran, Apidologie, 4(27), 307308.

Bigio, G., Schürch, R., Ratnieks, FLW. 2013. Hygienic behavior in honey bees (Hymenoptera: Apidae): effects of brood, food, and time of the year, Journal of Economic Entomology, 106(6):2280-2285.

Brückner, D. 1979. Effects of inbreeding on worker honeybees, Bee World, 60:3, 137-140, DOI: 10.1080/0005772X.1979.11097746.

Brückner, D,1980. Hoarding behaviour and life span of inbred, non-inbred and hybrid honeybees, Journal of Apicultural Research, 19(1), 35-41.

Cermak K. 1996. Effect of inbreeding on some characters of bees. Journal of Farm Animal Science (Slovakia), 29:217-222.

Cobey, SW. 2007. Comparison studies of instrumentally inseminated and naturally mated honey bee queens and factors affecting their performance, Apidologie, 38, 390-410.

Delaplane, KS., Pietravalle, S., Brown, MA., Budge, GE. 2015. Honey bee colonies headed by hyperpolyandrous queens have improved brood rearing efficiency and lower infestation rates of parasitic Varroa mites, PLoS ONE, 10 , e0142985. doi:10.1371/journal.pone.0142985.

den Boer SP, Boomsma JJ, Baer B. 2009. Honey bee males and queens use glandular secretions to enhance sperm viability before and after storage. Journal of Insect Physiology. Jun 1;55(6):538-43. 


\section{ARAŞTIRMA MAKALESI / RESEARCH ARTICLE}

El-Aw, MAM., Draz, KAA., Eid, KS., Abou-Shaara, $\mathrm{HFI}$. 2012. Measuring the morphological characters of honey bee (Apis mellifera L.) using a simple semi-automatic technique, J. Am. Sci, 8, 558-564.

Gerula, D., Węgrzynowicz, P., Panasiuk, B., Bieńkowska, M., Skowronek W. 2015. Hygienic behaviour of honeybee colonies with different levels of polyandry and genotypic composition, J. Apic. Sci.,59 (2): 107-113.

llyasov, R.A., Poskryakov, A.V., Petukhov, A.V., Nikolenko, A.G. 2015. Genetic differentiation of local populations of the dark European bee Apis mellifera mellifera L. in the Urals. Rus. J. Genet. 51: 677-682.

Ilyasov, R.A., Poskryakov, A.V., Petukhov, A.V., Nikolenko, A.G. 2016. Molecular genetic analysis of five extant reserves of black honeybee Apis mellifera mellifera in the Urals and the Volga region. Rus. J. Genet. 52: 828839.

Jeffree, EP.1958. A shaped wire grid for estimating quantities of brood and pollen in combs, Bee World, 58(3): 105-110.

Kaftanoglu, O., Peng, Y.-S. 1982. Effects of insemination on the initiation of oviposition in the queen honeybee, Journal of Apicultural Research, 21, 3-6.

Kelany, MM. 2018. Studies on some factors affecting honey bee (Apis mellifera L.) colonies in Toshka region, Egypt, PhD. Thesis, Fac. Agric. Sohag Univ.202 pp.

Moore, PA., Wilson, ME., Skinner, JA. 2015. Honey bee queens: Evaluating the most important colony member, http://articles.extension.org/pages/73133/hon ey-bee-queens:-evaluating-the-most-

important-colony-member. Accessed on 20/3/2017.

Moritz, RFA., Kryger, P., Allsopp, M. 1996. Competition for royalty in bees. Nature, 384, 522.

Oldroyd, BP., Allsopp, MH., Lim, J., Beekman, M. 2011. A thelytokous lineage of socially parasitic honey bees has retained heterozygosity despite at least 10 years of inbreeding. Evolution: International Journal of Organic Evolution, 65(3), 860-868.

Oldroyd, BP., Goodman, RD. 1988. Inbreeding and heterosis in queen bees in relation to brood area and honey production, Australian Journal of Agricultural Research, 39(5), 959-964.
Palacio, MA., Figini, E., Runengo, S., Rodriguez, E., del Hoyo, ML., Bedascarrasbure, EL. 2000. Changes in a population of Apis mellifera L. selected for hygienic behaviour and its relation to brood disease tolerance, Apidologie, 31 (4): 471-478.

Pernal, SF., Sewalem, A., Melathopoulos, AP. 2012. Breeding for hygienic behaviour in honeybees (Apis mellifera) using free-mated nucleus colonies, Apidologie, 43:403-416.

Radloff, SE., Hepburn, R., Bangay, LJ. 2003. Quantitative analysis of intracolonial and intercolonial morphometric variance in honeybees, Apis mellifera and Apis cerana, Apidologie, 34(4), 339-351.

Ratnieks, FLW., Keller, L. 1998. Queen control of egg fertilization in the honey bee. Behavioral Ecology and Sociobiology, 44, 57-61.

Roberts, WC. 1961. Heterosis in the honey bee as shown by morphological characters in inbred and hybrid bees, Annals of the Entomological Society of America, 54(6), 878-882.

Smith, NM., Wade, C., Allsopp, MH., Harpur, BA., Zayed, A., Rose, SA., Engelstädter, J., Chapman, NC., Yagound, B., Oldroyd, BP. 2019. Strikingly high levels of heterozygosity despite 20 years of inbreeding in a clonal honey bee, Journal of evolutionary biology, 32(2), 144-152.

Taber, III S., Wendel, J. 1985. Concerning the number of times queen bees mate. Journal of Economic Entomology, 51, 786-789.

Tarpy, DR., Keller, JJ., Caren, JR., Delaney, DA. 2012. Assessing the mating 'Health' of commercial honey bee queens. Journal of Economic Entomology, 105, 20-25.

Woyke J. 1963. What happens to diploid drone larvae in a honeybee colony. Journal of Apicultural Research, 2, 73-75.

Woyke J. 1964. Genetic proof of the origin of drones from fertilized eggs of the honeybee. Journal of Apicultural Research, 4, 7-11.

Xonis, C., Thrasyvoulou, A., El Taj, HF. 2015. Variability of hygienic behavior in bee Apis mellifera macedonica, Bulgarian Journal of Agricultural Science, 2015,21 (No 3) 674-679.

Yakoub, WA. Genetic improvement of some characteristics of the Syrian honey bee race. Ph.D. Thesis in Economic Entomology, Fac. of Agric., Alex. Univ. 2002.

Zmarlicki C., Morse RA. 1963. Drone congregation areas. J. Apic. Res. 2: 64-66. 